\title{
Enrolment Demand versus Accessibility at Canada's Universities
}

\section{ROBERT J. GIROUX}

Association of Universities and Colleges of Canada

\section{EDITORS' NOTE}

For this Special Feature, the editorial team invited Mr. Robert Giroux, Past President of the Association of Universities and Colleges of Canada, to reflect on changes to the system of higher education in Canada, as a follow-up to the remarks presented to the 2003 Annual Meeting of the Canadian Society for the Study of Higher Education. Mr. Giroux accepted our invitation, and his analysis, coupled with recommendations for significant new initiatives, are presented herewith.

\section{ABSTRACT}

An increasing number of young Canadians want the benefits of a university education, placing huge demands on Canada's universities. Our universities have responded to this demand by increasing enrolment significantly over the past several years, but per-student funding levels have not kept pace. This enrolment growth 
is unsustainable without increased government support to boost institutional capacity and hence accessibility. Without additional funds, either access or educational quality — or both - will suffer.

\section{RÉSUMÉ}

Un nombre croissant de jeunes Canadiens désire profiter des avantages que procure une éducation universitaire, ce qui met de la pression sur les universités canadiennes. Nos universités ont donc accepté davantage d'inscriptions au cours des dernières années mais le financement par étudiant n'a pas suivi le même rythme. Il ne sera donc pas possible de maintenir cette croissance sans un soutien accru du gouvernement pour stimuler la capacité institutionnelle et son accessibilité. Sans un financement additionnel, l'accès à l'enseignement ou la qualité de l'enseignement-ou même les deux - seront touchés.

\section{INTRODUCTION}

In the fall of 2002, the Association of Universities and Colleges of Canada made, what some considered, a rather bold prediction: that Canada's universities would face a 20 to 30 percent increase in enrolment by 2011 (AUCC, 2002). The claim was duly reported nation-wide in the media and engendered much discussion. But the projection was also met with some skepticism, particularly in light of the relatively flat university enrolment figures for Canadian universities in the mid-to-late 1990s.

As it turns out, our projections now seem quite conservative. In 2001 , there were roughly 646,000 undergraduate and graduate students enrolled full-time at Canada's universities and university degree-level colleges. Therefore, a 30-percent increase in enrolment would equate to just under 200,000 additional students in the system by 2011 . 
However, according to AUCC survey data, the last two years have seen the largest year-over-year enrolment increases ever seen in Canada, and this has already pushed up full-time enrolment by 100,000 students. In just two years, we are halfway to the total enrolment growth projected in the 30-percent growth scenario.

This enrolment growth far outstrips growth in the Canadian population. In the last three years, undergraduate enrolment has risen more than 10 times faster than the underlying population base. Provinces with the largest population growth over the past few years have seen enrolment increases, but even provinces that are experiencing population declines are witnessing strong enrolment growth. University enrolment is up right across Canada.

But we believe this enrolment growth is unsustainable in the long term without increased support, on a per-student basis, to university operating budgets. If universities are to ensure that there is a place for every qualified student, including those from traditionally disadvantaged groups, they must have sufficient institutional capacity to do so.

\section{Factors Pushing Enrolment Growth}

Population demographics play a role in rising enrolment, although they are of secondary importance. Between 1974 and 1991, there was a surge in the number of children born. These are the children of the baby-boom generation, often referred to as the "echo." These children are now reaching the age when they are beginning to enter university and their numbers will continue to grow over the 10-year period ending in 2011 (AUCC, 2002). The cohort of 18 - to 21 -year-olds is projected to rise by 8.5 percent during this time. This factor alone will likely push up undergraduate enrolment demand by about 35,000 students over the decade, if participation rates remain steady. But that is the key: participation rates are not remaining steady. They are growing significantly and are by far the biggest factor pushing university enrolment 
growth - a greater percentage of high school graduates are opting for a university education.

University participation rates are influenced by a myriad of factors, one of the most important being parental influence. Put simply, more and more Canadians want their children to go to university. This demand is greatest from parents who themselves went to university. In Canada, children whose parents have completed postsecondary education are more than twice as likely to complete postsecondary education than children whose parents did not complete secondary school (AUCC, 2002).

Data from the 2001 census indicate that many more adults in recent years have completed degrees than adults in the preceding generation. For example, in 2001, 19 percent of adults aged 45 to 54 held a university degree compared to just six percent 20 years earlier. Since many of the boomers' children will soon complete secondary school, it stands to reason that this group of more highly educated parents will create significant upward pressure on participation rates. They understand very clearly that a university education broadens their children's horizons and increases their opportunities.

Moreover, a recent Statistics Canada study found that more youths are completing high school and pursuing a postsecondary education (Statistics Canada, 2002). It indicates that the high school drop-out rate has declined from 18 percent in 1991 to 12 percent in 1999. It also suggests that two-thirds of those highschool graduates want to obtain a university degree. If even half of these graduates follow through on their intentions, this would lead to considerably stronger enrolment growth than we predicted in AUCC's 2002 report.

University participation rates also will continue to be influenced significantly by the growth of the knowledge economy and its emphasis on highly qualified professionals. Canadians have recognized and are increasingly responsive to these labour market signals. Similarly, participation rates are affected by Canadians' 
assessment of the value of a university education. While there is clearly concern about the growing costs of university, polls confirm that the public continues to believe in the value of the experience. For example, in a recent poll conducted for AUCC by Ekos Research Associates, 78 percent of respondents felt a university degree improves one's personal growth and quality of life, while 82 percent said it improves lifetime earnings and career advancement opportunities (AUCC, 2004). These beliefs are not misplaced: an AUCC analysis of the 2001 Census data reveals that a typical university graduate will earn, on average, $\$ 1$ million more over the course of his or her career compared to an individual with no postsecondary education.

But a university education is not just a wise personal investment. There are considerable public returns to this investment, as well. University graduates comprise only 15 percent of the population over the age of 18 , but they contribute almost 35 percent of all income taxes - more than twice their population share (AUCC, 2003b). Conversely, university graduates attract less than eight percent of government transfers, such as welfare payments and employment insurance, or half their population share.

Tax revenues from university graduates also figure prominently in the nation's ability to fund key social programs. Government investments in higher education help to create the economic wealth that is necessary to sustain and improve the quality of life for all Canadians. Moreover, the capacity for innovation that flows from a highly educated populace is a key factor in improving our national productivity, which in turn will lead to a higher standard of living and more wealth for the country.

Part of the innovation equation lies with the creation of new knowledge through research. Over the past 20 years, a consensus has emerged among economists and scholars about the many benefits of publicly funded research-particularly university research - and the high rates of return that one can expect of 
such investments. These expectations will likely generate strong demand for more research, more researchers, and greater research productivity in the coming decade.

Canadian universities perform much of the country's basic research and one-third of all national R\&D (AUCC, 2002). University research in Canada represents direct investments estimated at $\$ 6.8$ billion annually. Of that amount, $\$ 3.6$ millionmore than half - represents the universities' allocation of faculty time to research, provision of physical infrastructure, and other expenses related to research. The remaining sum, $\$ 3.2$ million, is sponsored research funded by government, the private sector, and other sources.

Governments at all levels in Canada have recognized the importance of research and innovation. The federal government, in particular, has built a solid foundation for research since 1997 with a number of key initiatives, including the Canada Foundation for Innovation, the Canada Research Chairs program, new Canada Graduate Scholarships, increased support for the direct costs of research through budget increases for the federal granting agencies, and partial support for the indirect costs of research through a new permanent program. These have generated a new sense of excitement on university campuses, and it is essential to maintain this momentum to enable Canadian researchers to push the frontiers of knowledge.

\section{Revitalizing the Educational Mission}

It is now time, and equally essential, that the educational mission of our universities be similarly revitalized. Institutional capacityuniversities' ability to accept more students and offer them a quality educational experience - must be increased. But the issue is not just one of capacity, but also of accessibility. Universities need to have the resources necessary not just to respond to growing enrolment demand, but to ensure that Canadians from all walks of life have 
equitable access to a university education. We anticipate that during the next decade students from lower income backgrounds and other traditionally disadvantaged groups will increasingly seek the economic and social advantage that a university education affords. If universities are to ensure that there is a place for these individuals, they must have the capacity to accept and support them.

Universities have been very responsive in attempting to accommodate rising student demand, but per-student funding levels have not kept pace, placing severe strains on their capacity. Rapid enrolment growth and cuts to public support have combined to reduce the real level of government support from more than $\$ 13,000$ per student in the late 1970 s to $\$ 10,000$ in 1990 and to just $\$ 8,000$ in the fall of 2003 (AUCC, 2003c). Looked at another way, by 2001 , Canadian governments were providing 20 percent less support in real per-student terms than they were two decades earlier. By contrast, U.S. state and federal governments were providing almost 30 percent more support per student at U.S. public universities than they did two decades earlier (AUCC, 2002).

\section{The Capacity Challenge}

There are two components to the capacity challenge that universities face in responding to growing demand. First, universities need more teachers. Second, they need more classroom and laboratory space. AUCC estimates that universities will need to hire almost 40,000 new faculty members by 2011 (AUCC, 2002). This is made up of at least 10,000 more faculty members to respond to the enrolment growth we expect. An additional 20,000 faculty will be needed to replace those who will leave the system, mainly due to retirement, but also through simple attrition. And universities will need to find up to 10,000 more faculty members to meet the growing demand for university research and to improve the quality of the educational and research experiences of those who will attend university in the coming years. 
With respect to the need for space, the growth in students and faculty further implies a need for additional classrooms and laboratories, libraries, and residences to house the university community and facilitate the work of that community. Universities will need additional new buildings and will need to upgrade older facilities. For example, a study by the Canadian Association of University Business Officers identified at least $\$ 3.6$ billion in accumulated deferred maintenance at Canadian universities (CAUBO, 2000).

Without adequate investment in institutional capacity, either accessibility or quality - or both-will suffer. In the 1980s, the OECD reported that Canada ranked as one of the leading nations in the world in university participation levels, just after the United States (OECD, 1994). However, university enrolment in Canada stagnated in the latter half of the 1990s. The very deep cutbacks in government support in earlier years virtually guaranteed that enrolment would not rise in the mid-1990s. When the deep cuts hit, universities increasingly looked to find savings by providing early retirement programs and by not replacing all the faculty and staff who chose to leave. If universities had had the resources to respond more fully to student demand in the mid-1990s, we believe enrolment would have increased.

Moreover, since 1980, universities had been increasing enrolment at the margins, for example, by adding to class sizes. By the mid-1990s, there was simply no more room to continue to do so-our universities were full. With no net increases from the combination of tuition fees and government grants, they simply could not or would not take on more students.

As a result of these restrictions, combined with very rapid increases in university participation in many other OECD countries, Canada's ranking in university participation levels has now dropped substantially. In fact, today approximately 19 percent of 18- to 21-year-olds in Canada are participating in university 
education - a figure that puts us in the middle of the pack (OECD, 2003). Our participation rates are well behind the top five nations of the OECD, all of which have surpassed, or are rapidly approaching, the 25-percent mark.

By the late 1990s, most provinces were once again providing enrolment incentives and beginning to build physical capacity in their institutions. Now, with several provinces facing deeper than expected fiscal problems, the ability of provinces to maintain the momentum created through their recent re-investments is in jeopardy. The provinces, through the Council of Ministers of Education, Canada, have been calling for federal government assistance in responding to growing student demand (CMEC, 2002). Those needs now have more urgency if we are to protect the recent gains in accessibility, and if we hope to broaden access even further.

In recent polling we did with the Canada Millennium Scholarship Foundation, 94 percent of the Canadian public answered yes to the question, "Should there be opportunities for postsecondary education for every qualified high-school graduate who wants to go?" However, when probed further on the issue, 30 percent of respondents were not very confident that such opportunities currently exist and a further 40 percent were only somewhat confident. It is, therefore, not surprising that when asked what should be the number one priority for postsecondary education, the survey respondents assessed guaranteeing access as the most important priority. However, for the youth cohort, especially those in the 18 to 24 age range, reducing fees was the number one priority.

\section{Tuition and Accessibility}

Over the course of the 1990s, fees did increase rapidly. Tuition fees continue to rise, but not quite at the same pace as during that period. The average undergraduate tuition fee for the 2003-04 school year is $\$ 4,025$, up 7.4 percent from $\$ 3,749$ the previous year 
(Statistics Canada, 2003). This is nearly double the Canadian average of $\$ 2,023$ (in current dollars) paid in 1993-94 and well above the rise in inflation during that time.

However, due to government cutbacks in per-student funding, noted above, rising tuition fees have not resulted in higher levels of revenue for universities on a per-student basis. There has simply been a shift from public funding to private funding, with no net gain to universities. As a result of these shifts, government support has fallen to just over 60 percent of operating revenues, whereas it stood at 83 percent of operating support in 1980 .

Some groups contend that rising tuition fees in the mid-1990s caused participation rates to level off. However, if one examines the trends over the last 30 years, a direct relationship between tuition fees and overall participation rates is quite difficult to establish. I am not suggesting that rising costs have had no impact on any individual's decision about whether to attend. However, while some individuals may indeed have been dissuaded from enrolling due to high tuition, others-sometimes from the same economic background-are waiting for the opportunity to take their place. So the problem is in determining how tuition increases impact different groups.

Survey data demonstrate that while participation levels are rising for children from all families, the gap between low- and middle-income groups grew between 1986 and 1998 (AUCC, 2002). Not surprisingly, this has fueled concern over equity of access in a society where education is increasingly perceived as essential to economic opportunity. In addition, universities are expected-appropriately - to be leaders in encouraging greater participation from underrepresented groups. Our country cannot afford to disenfranchise segments of our society, such as students from low-income families, Aboriginal Canadians, or individuals with disabilities.

As demand for education grows, it is increasingly important to use student aid measures to provide increased enrolment opportunities 
for students from all backgrounds. But it is not just money that will change enrolment behaviour. Students from poorer backgrounds need better information, better support and advice as they move through their school years so that they don't make decisions that effectively eliminate them from university opportunities.

If student aid and other measures to improve access for poorer students are to be successful, there must be space and support available in universities to accommodate these additional students. If, for example, participation levels in the lower-income groups rose sufficiently to reduce about half of the current participation gaps compared to those from higher income groups, then almost 100,000 new seats in university would be required (AUCC, 2003a).

If all we do is increase student aid, then we will just be increasing the level of demand without providing for any additional spaces to accommodate new students. Measures to increase the number of spaces and level of support for new students must go hand-in-hand with measures to increase the breadth and depth of student aid, otherwise more aid will just generate more demand that can't be met and create more frustration for students and parents.

For students to act on their educational aspirations, they have to believe that they have a real opportunity or a realistic chance to be offered a place in the institutions and programs in which they wish to enrol. A significant "discouraged student" phenomenon can develop when entry grades escalate to much higher levels than for earlier generations of students. Equitable access, therefore, has both student financial and institutional capacity dimensions.

\section{A Quality Educational Experience}

Crowding more students into existing campus facilities without attention to the quality of the educational experience is clearly not the answer. Canada's universities are called upon to provide the kind of quality education needed in a global future: active and collaborative learning experiences, high-quality interactions among students and 
faculty, and a strategic international component that will give our graduates a broad understanding of today's world. This will require more faculty and more staff to provide new and enhanced student services, including outreach and mentoring programs for nontraditional students; first-year experience programs to help young people make the transition to higher education; study skills and academic counselling services-all designed to help students not just enrol, but succeed.

In addition, Canada's universities are expected to be leaders in encouraging access for all learners - from young people who enter university directly from high school or CEGEP, to others who study part-time, to adults who want to take advantage of the opportunities that higher education affords its graduates. It is vital that no Canadians be denied the opportunity to benefit from a university education. Our country cannot afford to disenfranchise segments of our society.

The ability of Canadian universities to meet the challenges of increasing student participation, broadening accessibility, and developing the global skills and knowledge that students will require to thrive in today's world - in short, ensuring that universities provide Canadians with high-quality education - will depend fundamentally on increased investments in institutional capacity.

The federal government has an opportunity to provide for the education mission of universities the same kind of leadership it has shown with respect to university research. Provinces, for their part, will need to make sure that universities have the necessary operating resources to ensure quality while meeting enrolment pressures and encouraging broader access. Universities must make the best and most effective use of these resources.

\section{Higher Education Renewal Fund}

AUCC has proposed the development of a Canadian Higher Learning Strategy involving action in a number of areas over the next 
several years. The federal government could help the provinces and the universities to address the institutional capacity challenge through a Higher Education Renewal Fund. Meeting the renewal challenge would be a significant undertaking for the federal government and would entail a long-term commitment that would include new program development at the federal level, as well as a concerted effort to negotiate agreements with provincial governments to provide for appropriate levels of public accountability, transparency, and flexibility, while ensuring funds address capacity needs.

The Health Care Renewal Accord of 2003 provides a possible model for the Higher Education Renewal Fund. Broad elements of the Fund might include the development of a dedicated federalprovincial transfer mechanism over and above the Canada Social Transfer, with provisions designed to address faculty growth and other capacity-related needs, as well as dedicated federal funds in such areas as physical and technological infrastructure.

Working together, the federal government, Canada's universities, and other partners have achieved a great deal in developing the tools with which university research is contributing to the needs of a knowledge society. We need to consolidate and build upon these achievements. We must also begin the work of revitalizing higher education by addressing the issues of institutional capacity and accessibility. In the same spirit of partnership that has led to our success in research, universities, federal and provincial governments, and other stakeholders must come together, develop a robust strategy for higher education, and over time, implement a series of measures that will further enrich our society, enhance our competitiveness, improve our quality of life, and provide opportunities for all Canadians. 


\section{References}

Association of Universities and Colleges of Canada. (2002). Trends in Higher Education.

Association of Universities and Colleges of Canada. (2003a). Notes for a Presentation to the House of Commons Standing Committee on Finance.

Association of Universities and Colleges of Canada. (2003b). Special data request from Statistics Canada's Survey of Labour and Income Dynamics, 2001.

Association of Universities and Colleges of Canada. (2003c). Unpublished AUCC estimates updating the same analysis conducted in Trends, 2002.

Association of Universities and Colleges of Canada. (2004). Big benefits to a university education, say Canadians. Press release, Jan. 15.

Canadian Association of University Business Officers. (2000). A Point of No Return: The Urgent Need for Infrastructure Renewal at Canadian Universities.

Council of Ministers of Education, Canada. (2002). Working Together to Strengthen Learning and Labour Market Training.

Organization for Economic Cooperation and Development. (1994). Education at a Glance: OECD Indicators.

Organization for Economic Cooperation and Development. (2003). Education at a Glance database, special data request.

Statistics Canada. (2002). At a Crossroads: First Results for the 18-20-Yearold Cohort of the Youth in Transition Survey.

Statistics Canada. (2003). University tuition fees. The Daily, Aug. 12. 